\title{
ESTIMATION OF NET PRIMARY PRODUCTION (NPP) USING REMOTE SENSING APPROACH AND PLANT PHYSIOLOGICAL MODELING \\ (Pendugaan Net Primary Production (NPP) Menggunakan Pendekatan Penginderaan Jauh Dan Modeling Fisiologis Tanaman)
}

\author{
Yon Sugiarto', Tania June', Bambang Sapto $P^{2}$. \\ ${ }^{1}$ Department of Geophysics and Meteorology, Bogor Agricultural University, IPB Darmaga Campus, Bogor \\ 16680 INDONESIA \\ ${ }^{2}$ National Coordinating Agency for Survey and Mapping, I. Raya Jakarta - Bogor KM. 46 Cibinong 16911, \\ INDONESIA \\ E-mail: yons@ipb.ac.id
}

\begin{abstract}
Information Net Primary Production (NPP) of tropical forests is important for the development of realistic global carbon budgets and for projecting how these ecosystems will be affected by climate changes. This research utilized remotely sensed data and micrometeorological measurement to provide information on vegetation condition. The objective of this research is to estimate spatial NPP using remote sensing approach and plant physiological/micrometeorological modeling. The estimation of NPP is conducted using modeling approach, which is based on relationship between radiation use efficiency, photosyntetically active radiation and fraction of absorbed photosynthetically active radiation by the plants's canopy. Trend of NDVI derived using micrometeorological measurement showed an increase from 2001 to 2002, and then decrease from 2002 to 2004. Average different values (delta) between both methods used to derive NDVI is relatively constant around 0.33 with a high correlation of $r 2=0.98$. Using remotely sensed data, the highest NPP values estimated is in year 2003 with value range between $2000-2500$ (gC m-2 yr1), less than $2 \%$ of the whole forest area. In 2003, 75\% area has NPP between $1500-2000$ (gC m-2 yr-1), meanwhile for 2002 and 2004 it is only $21 \%$ and $50 \%$, respectively. NPP values estimated using micrometeorological measurement show the increasing of NPP values from 2002 to 2003, and then decrease from 2003 to 2004. There is strong correlation between NPP values derived from the two methods with $\mathrm{r} 2=0.98$.
\end{abstract}

Keywords: micrometeorological modeling, net primary production (NPP), photosyntetically active radiation (PAR), remote sensing, vegetation.

\section{INTRODUCTION}

\section{Background}

Human-driven changes in land use and land cover are by far the most dominant component of global change in terms of impacts on terrestrial ecosystems. Land use and land cover changes are one of the fundamental phenomena in the earth system's dynamics. Land cover change in the tropical region country such as Indonesia is concentrated on the conversion of forest to more intensively managed system. The Indonesian issue of land use and land cover changes becomes more critical, as the population living in the archipelago increases, leading to the increase in the demand for space, and the complexity of activities potentially changing the land cover and land uses at a more rapid pace. Land cover and land use changes, including from deforestation, in Indonesia has been showing a significant magnitude in the last 50 years (Frederick et al. 2001).

Penyerahan naskah

: 20 November 2008

Diterima untuk diterbitkan

: 11 Desember 2008 
Net primary production (NPP) is the difference between total photosynthesis (Gross Primary Production, GPP) and total plant respiration in an ecosystem. NPP is a fundamental ecological variable, not only because it measures the energy input to the biosphere and terrestrial carbon dioxide assimilation, but also because of its significance in indicating the condition of the land surface area and status of a wide range of ecological processes. Information on NPP in tropical forests is needed for the development of realistic global carbon budgets, for projecting how these ecosystems will be affected by climatic and atmospheric changes, and for evaluating eddy covariance measurements of tropical forest carbon flux.

NPP is able to describe the net flux of carbon from the atmosphere into green plants per unit time. NPP refers to a rate process, i.e., the amount of vegetable matter produced (net primary production) per day, week, or year. There are many ways to estimate terrestrial NPP from field measurements that depend on the type of plants and available measurements. Study about NPP for tropical forest is very important, because Indonesia is one of the countries located in the tropical area. Indonesia has large area of tropical forest. Dixon et al. (1994) declared that tropical forests are disproportionately important in the world carbon budget, representing an estimated $59 \%$ of the global carbon pool in forests. Although they are only $22 \%$ of potential vegetation by area, tropical evergreen and deciduous forests have been estimated to account for $32 \%$ to $43 \%$ (Melillo et al. 1993) of the world's potential terrestrial NPP.

An important current research need is to develop a better understanding of NPP in the world's forests, ecosystems that play a major role in the global carbon budget (Dixon et al. 1994). While unprecedented atmospheric concentrations of the greenhouse gas carbon dioxide $\left(\mathrm{CO}_{2}\right)$ continue to increase due to anthropogenic activities, large uncertainties affect current understanding of the world's carbon budget (Melillo et al. 1996). Such improvements in our understanding of forest carbon dynamics can then be used to develop better policy decisions related to forest production or conservation (Clark et al. 2001).

Remote sensing techniques used in relatively simple modeling frameworks to estimate global NPP of terrestrial vegetation using the relationship between reflectance properties and absorption of photosynthetically active radiation (PAR), if net conversion efficiencies can be approximated or assumed nearly constant (Ruimy et al. 1994). NPP can be also estimate using the difference between total photosynthesis (GPP) and total plant respiration in an ecosystem. The difficulty in using this approach as the basis for estimating NPP in the field lies in the uncertainties associated with the estimation of respiration. NPP can also be estimated from information about biomass dynamics. An attractive approach for estimating NPP using modeling proposed by Monteith $(1972,1977)$ and June (2004), which is based on relationship between radiation use efficiency (e), photosyntetically active radiation (PAR) and fraction of absorbed photosynthetically active radiation (fAPAR). NPP $\left(\mathrm{gC} \mathrm{m}^{-2}\right.$ year $\left.{ }^{-1}\right)$ is determine as $\mathrm{dC} / \mathrm{dt}$ (carbon accumulation over time; when time $=I$ year $\mathrm{dC} / \mathrm{dt}=\mathrm{NPP}$ ) as a product of the efficiency of the canopy (June, 2004). 
Yon Sugiarto, Tania June dan Bambang Sapto P.

\section{Objectives}

There are several objectives designed for this research, which are:

a. Study vegetation indices derived from micrometeorological measurement and from remotely sensed data

b. Estimating NPP from peat swamp forest using remote sensing approach and plant physiological / micrometeorological modeling

The result of this research could be used to estimate the total of carbon absorbed by forest vegetation (carbon sink) and shows a range of forest carbon storage potentials.

\section{Hypothesis}

This research used remote sensing approach and plant physiological modeling to derive some parameters and variables used in NPP modeling. The remote sensing approach has advantage in order to derive spatial result, but it should be comparing with the micrometeorological modeling based on in situ measurements. Different methods of NPP estimating will cause the different result of NPP simulated but still in the same pattern or trend. Considering the environmental condition, there is also a relationship between climate condition and the result of NPP simulated.

\section{RESEARCH METHODOLOGY}

\section{Research Location and Data Source}

Study area of this research is a natural peat swap forest (in Area B of the Mega Rice Project) at Kalampangan, located at near Palangkaraya city in Central Kalimantan. Peat swamp forest in Central Kalimantan has been recognized as one of the significant sinks for fixing atmosphere carbon. In Kalampangan site, there are four land cover classification, which are natural forest, regenerating forest, burn forest and agricultural land. The height of the forest canopy is about $26 \mathrm{~m}$, where forest is located between the Sebangau River and a channel running from north to south. Location of the study and one of the Landsat ETM data used is shown in Figure 1.
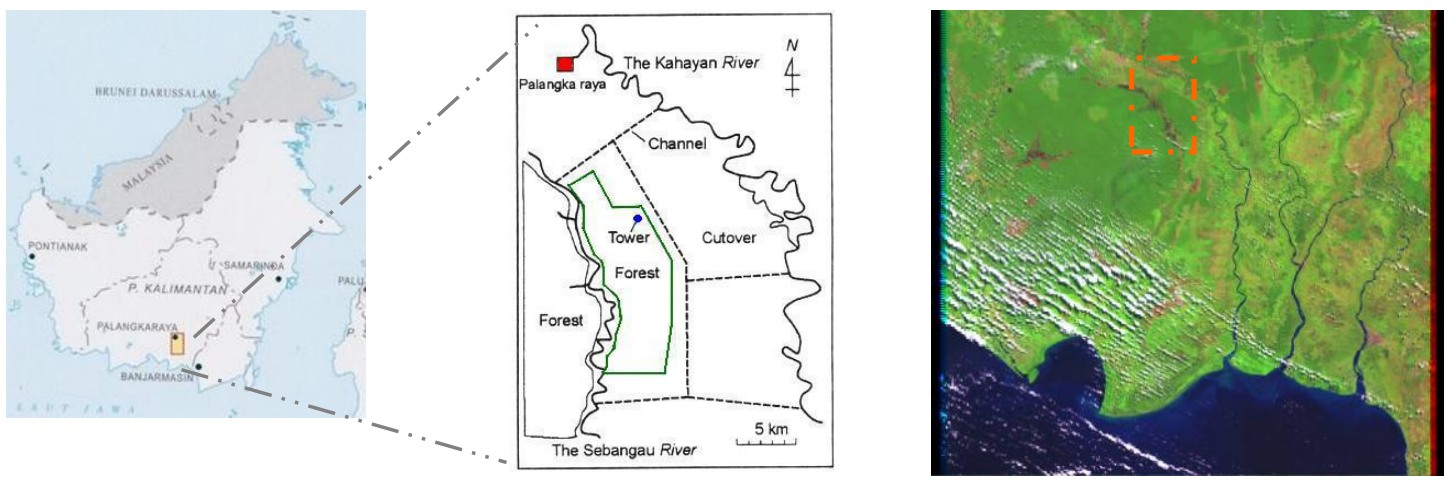

Figure 1. Location of the study area and sample of Landsat ETM data 
This research used spatial data (Landsat 7 ETM+ year 2000, 2001, 2003 and 2004 path 198 row 62, Land use and land cover map of study area with scale $1: 250.000$, produced by Bakosurtanal) and non spatial data ( micrometeorological data from tower at Kalampangan, Center Kalimantan : solar radiation, PPPFD, relative humidity, temperature, rainfall, wind speed, wind direction).

\section{Methodology}

\section{Data Collecting}

Remote sensing data used for this research is Landsat 7 ETM+ image acquired at 2000, 2001, 2003 and 2004. The sources of remote sensing data for 2001 and 2003 are from Landsat.org-Indonesia and TRFIC, meanwhile for 2004 is supported by Core University Program Project between Japan and Indonesia. A continuous micrometeorological measurement tower with $50 \mathrm{~m}$ high was installed approximately 300 inside the northeast corner of the forest with position $2^{\circ}$ 2' $41.6^{\prime \prime} \mathrm{S}, 114^{\circ} 2^{\prime} 11.3^{\prime \prime} \mathrm{E}$. This station is collaborated between Bogor Agricultural University, LIPI Indonesia and Hokkaido University, Japan, began measured at the middle of July 2001 and provided climatic data for this research. Daily radiation was measured using radiometer installed at $40.6 \mathrm{~m}$ height. Precipitation was measured at $41.0 \mathrm{~m}$ with a tipping bucket rain gauge. Air temperature and relative humidity were measured at 41.7 and $2 \mathrm{~m}$ with platinum resistance thermometer and capacitive hygrometers. Data micrometeorological used for this research is from August 2001 until December 2004.

\section{Remote Sensing Analysis}

Basic image processing conducted to preparing the remote sensing data for further analysis. Sub sampling image conducted to select forest area trough cropping method, meanwhile vector data used to cropping area peat swamp forest. This research used unsupervised classification to classify result of vegetation indices analysis such as NDVI and LAI. The output of this image classification process is classification of range value of NDVI and LAI. Image classifications also used to create map display of NPP that contain range of NPP estimated from the study area. The number of classes of NDVI, LAI and NPP will depend on the statistic analysis of the images.

\section{Estimation of Normal Different Vegetation Index (NDVI)}

The normalized different vegetation index (NDVI), which is related to the proportion of photosyntetically active radiation, is calculated from atmospherically corrected reflected from the near infrared and red of remote sensing data. From micrometeorological measurement, NDVI values was derived using equation introduced by (Huemmrich et al., 1999). The NDVI value will calculated using data measured between 10.00 WIB and 14:00 local time when downward shortwave radiation was larger that 600 watt $\mathrm{m}^{-2}$. The equation used is shown below: 


$$
N D V I=\frac{\left(\rho_{a R-} \rho_{P A R}\right)}{\left(\rho_{a R+} \rho_{P A R}\right)}
$$

Where $\rho_{\mathrm{OIR}}$ is optical infrared reflectance and $\rho_{\mathrm{PAR}}$ is PAR reflectance. $\rho_{\mathrm{OIR}}$ and $\rho_{\mathrm{PAR}}$ is function of radiation and PPFD measured in micrometeorological instrument.

$$
\begin{aligned}
& \rho_{P A R}=\frac{E_{P A R r e f}}{E_{P A R}} \\
& \rho_{Q R}=\frac{\left(S_{r-r e f}-E_{P A R-r e f}\right)}{\left(S_{r}-E_{P A R}\right)} \\
& E_{P A R}=0.25 * P P F D \text { and } E_{\text {PAR }}=0.2 \text { F PPFF }
\end{aligned}
$$

$E_{P A R}$ is downward PAR $\left(\mathrm{Wm}^{-2}\right)$ while $\mathrm{E}_{\text {PARref }}$ is upward (reflected) PAR. $\mathrm{S}_{\text {r-ref }}$ is upward short-wave radiation and PPFD ref is upward (reflected) PPFD $\left(\mu \mathrm{mol} \mathrm{m} \mathrm{m}^{-2} \mathrm{~s}^{-1}\right)$.

\section{Estimation of Leaf Area Index (LAl)}

Estimation LAI will be done using equation introduced by Ibrahim (2001). Linear relationship between $L A I$ and NDVI using Landsat TM data estimated through the equation as:

$$
L A I=12.74 * N D I+1.34
$$

\section{Estimation of $f_{\text {APAR }}$ and PAR}

Estimation of $f_{A P A R}$ will be done using equation introduced by Ruimy et al. (1994). The relationship between fAPAR and NDVI is shown in equation:

$$
f_{A P A R}=1.25 * N D M-0.025
$$

PAR is part of shortwave radiation from the sun in range bertween $0.4-0.7 \mu \mathrm{m}$, derived from direct measurement using quantum sensor that record photosyhentetic photon flux densities (PPFD) in $\mu \mathrm{m} \mathrm{m}^{-2} \mathrm{~s}^{-1}$. PAR could also estimate using micrometeorological modeling. In this research, PAR used for NPP calculation from tower measurement derived from PPFD measured at $40.6 \mathrm{~m}$ in tower. The relationship between PAR and PPFD is shown in equation:

PARO25PPF

PAR used for NPP calculation from remotely sensed data is derived from WIMOVAC micrometeorological modeling. WIMOVAC as micrometeorological modeling is a software package for modeling the dynamics of plant leaf and canopy photosynthesis.

\section{Radiation Use Efficiency (e)}

Radiation use efficiency is defined as $\mathrm{mol} \mathrm{CO}_{2}$ assimilated per mol absorbed light. In this research, based on the study site characteristic, sunlit/shaded model is used to derived canopy assimilation rate (Ac) and radiation absorption by canopy (IC) using WIMOVAC modeling. To calculate e value, the relationship between $\mathrm{Ac}$ and $\mathrm{Ic}$ is shown in equation:

$$
e=\frac{A c}{I c}
$$


The value of e can be considered as a constant value or changes daily based on the changing climate and plant parameter like leaf area index (LAI). However, in order to make it responsive to the changing environmental condition, or to be used for a climate change prediction effect on NPP, e has to be estimated using mechanistically or semi mechanistically model (June, 2004).

\section{Net Primary Productivity (NPP) Modeling}

The approach for NPP modeling is conducedt using relationship between radiation use efficiency (e), photosyntetically active radiation (PAR) and fraction of absorbed photosynthetically active radiation (fAPAR)(June, 2002). Radiation use efficiency value is a function of climate condition, vegetation type and leaf area index. PAR is a solar radiation energy that used in photosynthetic process, and fAPAR is part of PAR that absorb by plant canopy. The equation use for estimation annual NPP values is:

$$
N P P=\sum_{i=1}^{365} e * f A P A R * P A R
$$

where: $\mathrm{NPP}=$ net primary productivity $\left(\mathrm{gC} \mathrm{m}^{-2}\right.$ year $\left.{ }^{-1}\right), \mathrm{e}=$ radiation use efficiency $\left(\mathrm{gC} \mathrm{MJ}^{-1}\right), \mathrm{PAR}=$ photosyntetically active radiation $\left(\mathrm{MJ} \mathrm{m}^{-2}\right.$ day $\left.^{-1}\right), \mathrm{APAR}=$ fraction of absorbed PAR.

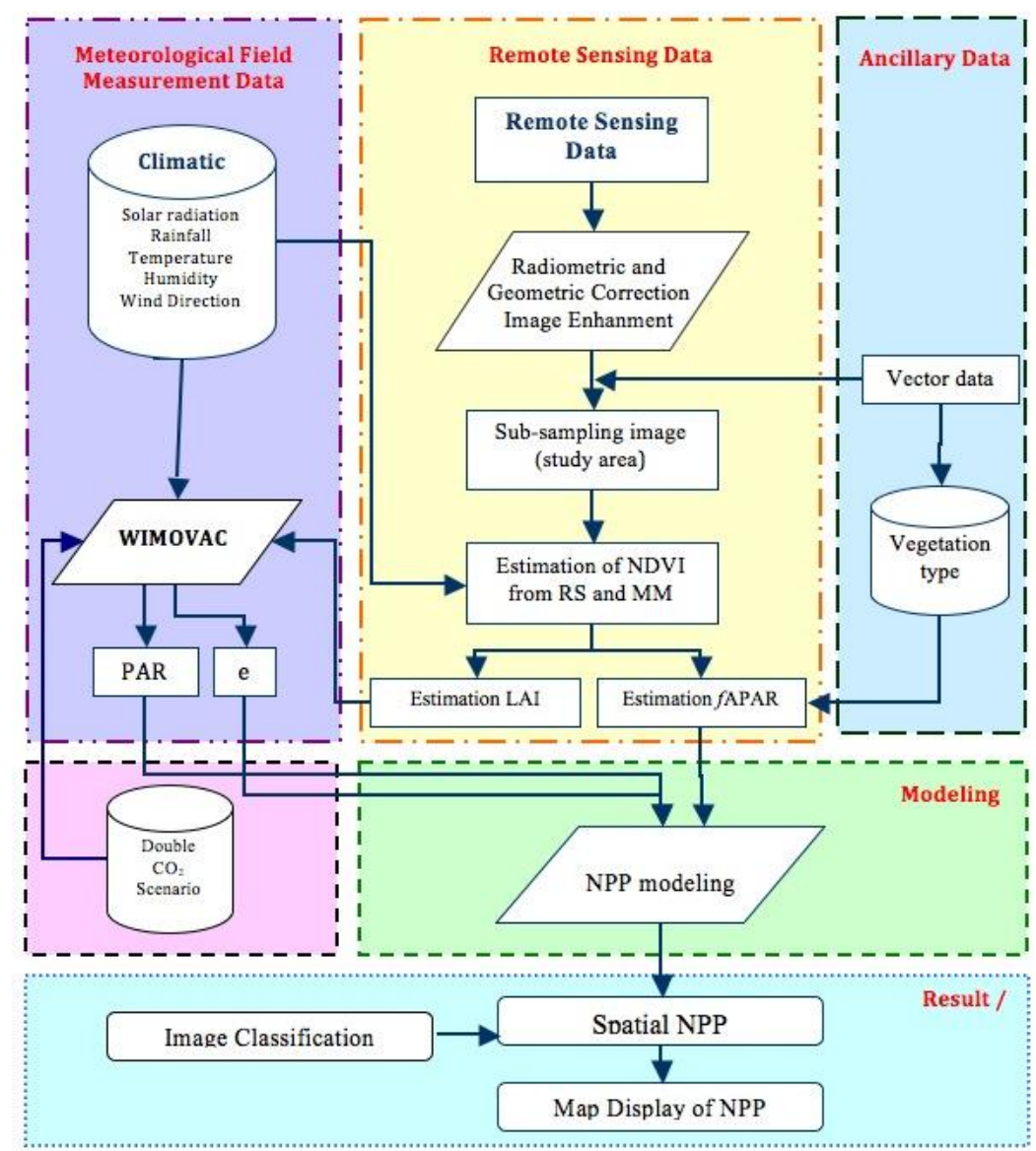

Figure 2. Flowchart of the research 
Yon Sugiarto, Tania June dan Bambang Sapto P.

\section{RESULT AND DISCUSSION}

\section{Study Area Description}

\section{Physical and Environmental Condition}

Central Kalimantan is characterized by a tropical climate with a distinct rainy and dry season, a vast area of peat swamp forest and occurrence of wildfire. Peat swamp forest in Central Kalimantan has been recognized as one of the significant sinks for fixing atmosphere carbon. In Kalampangan site, there are four land cover classification, which are natural forest, regenerating forest, burn forest and agricultural land. This area is near the equator, its make this area have equatorial type of the rainfall. This rainfall type indicated with two peaks of rainfall in a year. Figure 3 shown the average climatic variable (rainfall, temperature and humidity) for 2001 to 2004 at research site in Kalampangan.
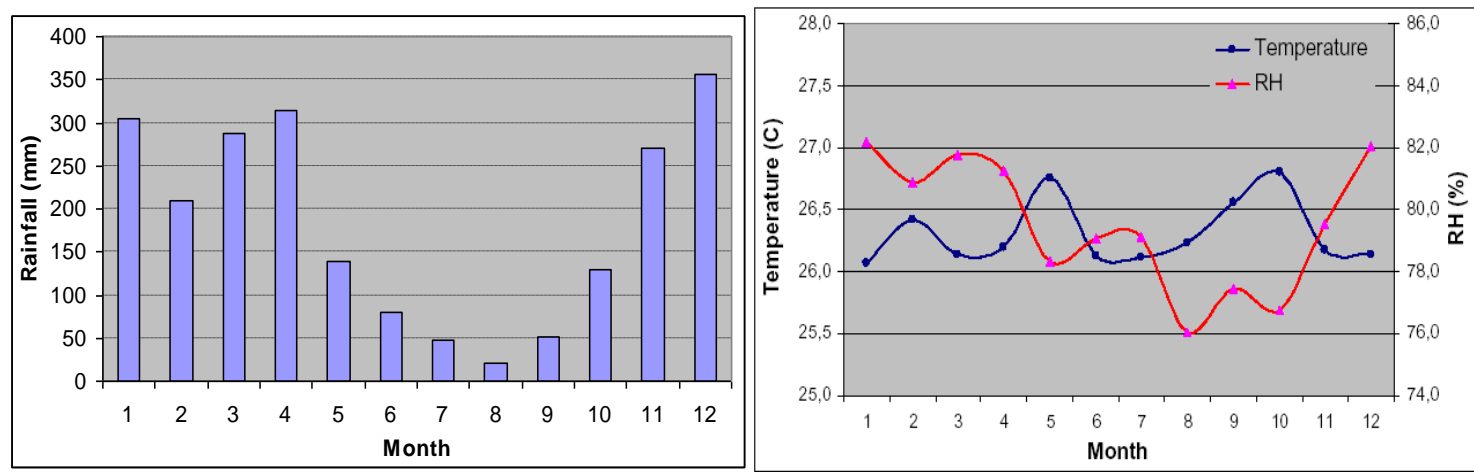

Figure 3. Monthly average rainfall, air temperature abn RH measured since 2001 to 2004

The rainfall data recorded in kalampangan site shown that rainy season with rainfall larger that $200 \mathrm{~mm} \mathrm{month}^{-1}$ is start at November until April. The dry season is started at April and ended at September or October. The dried month with less rainfall is on August. There are two peaks of monthly rainfall in year which are April and December. Based in earth-sun position relationship, the sun will locate in the equator twice in a year, on March and September. The moving of sun will bring the large of sun energy, heating the surface and created a large evaporation to the atmosphere that will create massive cloud development around the equator. Area within the equator with active cloud development and form called ITCZ (inter tropical convergent zone). That's explaining the reason where Kalampangan site that located near the equator is having two peaks of rain in a year.

Furthermore, based on type of Indonesian rain pattern, area of Indonesia divided become three pattern of rainfall; that is Monsoon, equatorial and local pattern. Monsoon pattern has the character of unimodal (one peak rains that is around December). During six-month of high rainfall relative (usually referred by the rain season) and next six-month lower (usually called as dry season). In general, dry season take place from April until September and the rainny season start 
on October until March. Pattern of Equatorial is characterized by rain pattern with form of bimodal, that is two rain top which usually happened around March or April and October or November when sun moment reside in near by equator. Local pattern having character where the rain pattern is form of unimodal (one rain top) but its have opponent rain pattern with type of monsoon.

\section{Microclimate Condition during 2001 - 2004}

Table 1 is shown yearly microclimate variation from August 2001 to December 2004. Average of daily solar radiation, net radiation and PPFD are lowest on 2002 and relatively constant in other years. The total precipitation is below $2000 \mathrm{~mm}$ year-1, meanwhile other year is above $2000 \mathrm{~mm}$ year ${ }^{-1}$. Air temperature and relative humidity is highest in 2002 compare to others. Daily average of wind speed is relative constant from $2001-2004$. This data shown that in 2002, the atmospheric condition is different with other years. The phenomena ENSO which is moderate EI Nino that came started on mid 2002 (IRI, 2003), possibly is a factor that caused this microclimate variation in the location.

Table 1. Yearly microclimatic variations from August 2001 to December 2004

\begin{tabular}{cccccccr}
\hline Year & $\begin{array}{c}\mathbf{S r} \\
\mathbf{M J m}^{-\mathbf{2}} \mathbf{d}^{-\mathbf{1}}\end{array}$ & $\begin{array}{c}\mathbf{R n} \\
\mathbf{M J m}^{-\mathbf{2}} \mathbf{d}^{-\mathbf{1}}\end{array}$ & $\begin{array}{c}\mathbf{P P F D} \\
\mathbf{m o l m}^{-\mathbf{2}} \mathbf{d}^{-\mathbf{1}}\end{array}$ & $\begin{array}{c}\mathbf{T} \\
{ }^{\circ} \mathbf{C}\end{array}$ & $\begin{array}{c}\mathbf{R H} \\
{ }^{\circ} \mathbf{C}\end{array}$ & $\begin{array}{c}\mathbf{V} \\
\mathbf{~} \mathbf{~ s}^{-\mathbf{1}}\end{array}$ & $\begin{array}{c}\mathbf{P} \\
\mathbf{~ m m}\end{array}$ \\
\hline 2001 & 17.7 & 13.4 & 37.5 & 26.1 & 79.6 & 1.8 & 764.3 \\
2002 & 16.6 & 12.1 & 35.2 & 26.7 & 80.2 & 1.8 & 1851.5 \\
2003 & 17.4 & 13.1 & 39.3 & 26.4 & 78.4 & 1.8 & 2290.5 \\
2004 & 17.3 & 12.8 & 34.6 & 25.9 & 79.5 & 1.8 & 2559.2 \\
\hline \multicolumn{7}{r}{ Monthly microclimatic variations from August 2001 to December 2004 are shown in Figure }
\end{tabular}

4. Average of daily solar radiation during $2001-2004$ is relatively constant $15-20 \mathrm{MJ} \mathrm{m}^{-2}$ day $^{-1}$, except for mid of 2002 that decreased lower that $15 \mathrm{MJ} \mathrm{m}^{-2}$ day ${ }^{-1}$. It has been discussed in previous, that the dry season in Kalampangan site is started in mid of year and reaches the peak at August / September. Photosynthetic flux photon densities (PPFD) have similar trend with solar radiation; it decreases on mid 2002 and back to normal pattern on the end of 2002. Average of daily PPFD is $30-45 \mu \mathrm{mol} \mathrm{m} \mathrm{m}^{-2}$ day $^{-1}$. Solar radiation (Sr) and PPFD were high in the dry season, but this did not happen in 2002. This was due to the shading caused by the smoke emitted from large scale peat land fires around the forest.

Daily mean air temperature relatively constant for 2001 - 2004 with range between 25.0 $28.0^{\circ} \mathrm{C}$. Trend of air temperature is lower in 2003 and 2004 compare to 2002. Table 1 was shown that, the air temperature in 2004 is lowest with daily average 25.9. $\mathrm{RH}$ is also relative constant in range between $70-85 \%$, but it can be shown that $\mathrm{RH}$ is decrease since mid 2002 and constant in range below $80 \%$. $\mathrm{RH}$ is ratio between actual vapor pressure $\left(\mathrm{e}_{\mathrm{a}}\right)$ and saturated vapor pressure $\left(e_{s}\right)$. The increasing of air temperature will followed with increasing of es. In the atmosphere, the increasing of air temperature is usually followed by decreasing of $\mathrm{RH}$. In this case, it is possible that increasing of air temperature also increase the water evaporated to atmosphere that increasing water content in atmosphere. It is because the area is peat swamp forest that content more moisture used to evapotranspiration process. The trend of precipitation is constant for 2001 -2004 , with two peaks of rainy in a year and less rain started in Mei - September. In December 
Yon Sugiarto, Tania June dan Bambang Sapto P.

2004 , monthly precipitation is above $500 \mathrm{~mm} \mathrm{month}^{-1}$, the highest for total month in period 2001 2004.

\section{Vegetation Indices}

NDVI of the area derived from remotely sensed data relatively small. Although the maximum NDVI for forest at Kalampangan site is between $0.4-0.5$, but the highest percentage of NDVI value is only between $0.3-0.4$. In year 2001, the highest percentage of NDVI is between 0.2 - 0.3 (81\% of site), and between $0.3-0.4(14 \%)$. In 2002, the pattern same with 2001, where the highest percentage of NDVI is between $0.2-0.3$ (55\% of site) and between $0.3-0.4(41 \%)$. In 2003, the highest percentage of NDVI is between $0.3-0.4$ (59\% of site) and between $0.4-0.5$ (31\%). The increasing of NDVI in year 2003 did not follow by NDVI condition in 2004, where the NDVI then decreased where the highest percentage of NDVI is between $0.2-0.3$ ( $55 \%$ of site) and between $0.3-0.4(39 \%)$.

Table 2 Distribution of NDVI at Kalampangan site derived from remote sensing data year 2001 2004

\begin{tabular}{crrrrrr}
\hline Year & $<\mathbf{0 . 1}$ & $\mathbf{0 . 1} \mathbf{- 0 . 2}$ & $\mathbf{0 . 2}-\mathbf{0 . 3}$ & $\mathbf{0 . 3}-\mathbf{0 . 4}$ & $\mathbf{0 . 4}-\mathbf{0 . 5}$ & Total (ha) \\
\hline 2001 (ha) & 153.5 & 903.2 & 15962.4 & 2784.2 & 0.0 & 19,803 \\
$\%$ & 1 & 5 & 81 & 14 & 0 & \\
2002 (ha) & 16.8 & 562.1 & 10672.2 & 7968.1 & 15.2 & 19,234 \\
$\%$ & 0 & 3 & 55 & 41 & 0 & \\
2003 (ha) & 173.3 & 543.5 & 1147.0 & 11314.5 & 6021.4 & 19,200 \\
$\%$ & 1 & 3 & 6 & 59 & 31 & \\
2004 (ha) & 372.0 & 849.5 & 10754.7 & 7608.8 & 0.0 & 19,585 \\
$\%$ & 2 & 4 & 55 & 39 & 0 & \\
\hline
\end{tabular}

Figure 4 shown daily NDVI and LAI analyzed using micrometeorological measurement. The result show the fluctuation of NDVI and LAI that caused by season. NDVI is relatively constant between $0.6-0.8$ at the end of 2001 until mid 2002. NDVI started to decrease in mid of 2002 until November 2002. The dry season at study area is started on mid year, reach peak of dry season on August and ended in November. It can explain why NDVI values relatively low in mid year. Furthermore, the decreased of NDVI values in 2002 caused by the phenomena El Nino that came from mid year of 2002 until end of 2002.

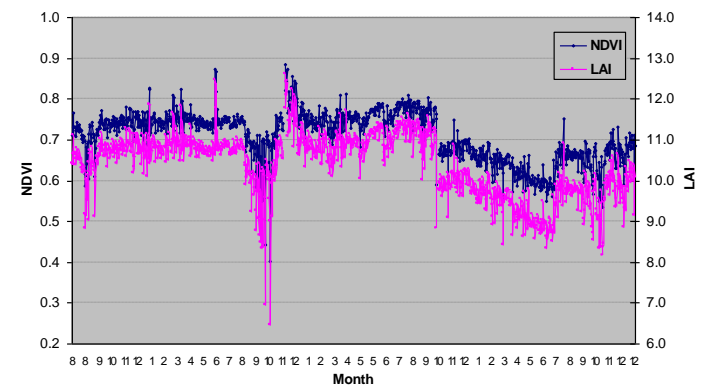

Figure 4 Distribution of daily NDVI and LAI at Kalampangan site derived from remote sensing data year $2001-2004$ 
Table 3 shown comparisons of NDVI and LAI derived from remotely sensed data and tower micrometeorological measurement year 2000 - 2004. The comparisons of NDVI from both methods shown in Figure 6. NDVI values different from both methods are different, but delta and trend is similar. Different values of NDVI derive from remote sensing approach and in situ measurement is constant in range 0.33-0.34. This is shown that there is another factor involved in the process for both. remotely sensed data and micrometeorological measurement data. This is quite difficult to determine. which one is more right or better. Both approach have unique method to acquire the data and processed to vegetation indices.

Table 3. Comparison of NDVI and LAI derived from remotely sensed data and micrometeorological measurement year $2000-2004$

\begin{tabular}{llccccc}
\hline & & $\mathbf{2 0 0 0}$ & $\mathbf{2 0 0 1}$ & $\mathbf{2 0 0 2}$ & $\mathbf{2 0 0 3}$ & $\mathbf{2 0 0 4}$ \\
\hline NDVI from RS & Minimum & 0.01 & 0.01 & $*$ & 0.01 & 0.01 \\
& Mean & 0.34 & 0.26 & $*$ & 0.32 & 0.28 \\
\multirow{4}{*}{ NDVI from tower } & Maximum & 0.56 & 0.44 & $*$ & 0.49 & 0.42 \\
& Mean & $*$ & 0.73 & 0.74 & 0.74 & 0.64 \\
\multirow{2}{*}{ NDVI (RS and Tower) } & Maximum & $*$ & 0.78 & 0.88 & 0.81 & 0.75 \\
LAl from RS & Mean & $*$ & 0.47 & $*$ & 0.42 & 0.36 \\
& Maximum & $*$ & 0.34 & $*$ & 0.33 & 0.33 \\
& Minimum & 1.45 & 1.41 & $*$ & 1.40 & 1.40 \\
\multirow{2}{*}{ LAI from tower } & Mean & 5.62 & 4.65 & $*$ & 5.41 & 4.93 \\
& Maximum & 8.42 & 6.91 & $*$ & 7.53 & 6.66 \\
\multirow{2}{*}{$\Delta$ LAI (RS and Tower) } & Mean & $*$ & 10.61 & 10.75 & 10.79 & 9.52 \\
& Maximum & $*$ & 11.27 & 12.60 & 11.70 & 10.91 \\
& Mean & $*$ & 5.97 & $*$ & 5.38 & 4.59 \\
& Maximum & $*$ & 4.37 & $*$ & 4.18 & 4.25 \\
\hline${ }^{*}:$ data
\end{tabular}

( ${ }^{*}$ data not available)

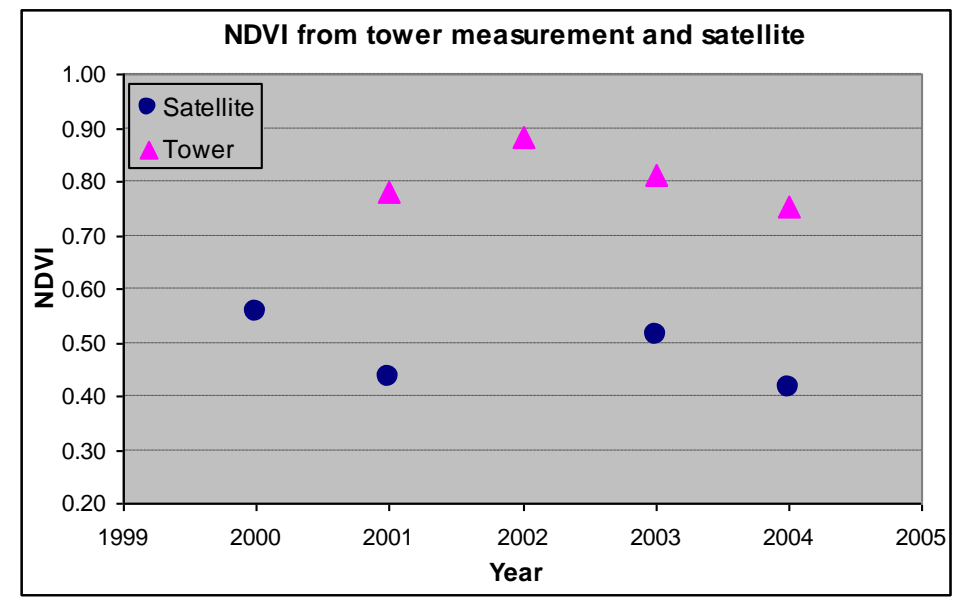

Figure 6. Comparison of NDVI at Kalampangan site derived from remote sensing and micrometeorological measurement data year $2001-2004$

\section{Net Primary Production}

The net flux of carbon between the atmosphere and terrestrial vegetation can be expressed on an annual basis in terms of net biomass accumulation or net primary production (NPP). Several methods of estimating NPP over large areas have been established. Some are 
Yon Sugiarto, Tania June dan Bambang Sapto P.

based on complex ecophysiology models that link carbon and nutrient cycles, while others utilize remotely sensed data to provide information on vegetation condition and to monitor changes in leaf area index or canopy light absorption through time. NPP values in this research was estimated based on the utilization of remotely sensed data to provide information on vegetation condition and estimated by micrometeorological measurement by integrating radiation use efficiency (e). photosyntetically active radiation (PAR) and fraction of absorbed photosynthetically active radiation (fAPAR).

\section{NPP from remote sensing approach}

NPP values from peat swamp forest at Kalampangan has estimated form year 2001 2004. Due to the lack data micrometeorological recorded at Kalampangan site, NPP for year 2001 was estimated using data from September 2001 - December 2001. Continuous micrometeorological measurement from tower provides micrometeorological data that can be used to estimate NPP for year $2002-2004$.

NPP derived from remote sensing approach mean that remotely sensed data was used to provide information on vegetation condition and to monitor changes in leaf area index. Vegetation condition that represented by NDVI then used to estimated AAPAR value. Due to the limitation of remote sensing data availability, function of vegetation condition used to estimating NPP is only for monthly. Monthly radiation use efficiency (e) derived from average of daily data as the result of WIMOVAC modelin, meanwhile monthly of photosyntetically active radiation (PAR) derived from sum of daily data recorded at tower measurement. All the parameter above then has been integrated using equation 19 to estimated NPP values.

The peat swamp forest at Kalampangan site has area around 1900 ha. The result of NPP estimated shown that the highest NPP value is in year 2003. The maximum NPP is between 2000 - 2500 ( $\mathrm{gC} \mathrm{m}-2 \mathrm{yr}-1$ ), but it is only for small area which are less than $2 \%$ from whole area that around 1900 ha. In 2003, 75\% area has NPP between 1500 - 2000 (gC m-2 yr-1), meanwhile for 2002 and 2004 area that has NPP between 1500 - 2000 (gC m-2 yr-1) only $21 \%$ and $50 \%$ respectively.

Table 4 Distribution of NPP at Kalampangan site derived from remote sensing data year 2001 2004

\begin{tabular}{|c|c|c|c|c|c|c|}
\hline \multirow{2}{*}{ Year } & \multicolumn{5}{|c|}{ NPP (gC m-2 yr-1) } & \multirow{2}{*}{ Total (ha) } \\
\hline & $<500$ & $500-1000$ & $1000-1500$ & $1500-2000$ & $2000-2500$ & \\
\hline 2001 (ha) & 146.8 & 672.8 & 8670.7 & 9367.2 & 5.2 & 18,863 \\
\hline$\%$ & 1 & 4 & 46 & 50 & 0 & \\
\hline 2002 (ha) & 102.2 & 799.0 & 14355.1 & 3976.7 & 15.2 & 19,248 \\
\hline$\%$ & 1 & 4 & 75 & 21 & 0 & \\
\hline 2003 (ha) & 0.0 & 381.3 & 4018.2 & 13864.6 & 178.7 & 18,443 \\
\hline$\%$ & 0 & 2 & 22 & 75 & 1 & \\
\hline 2004 (ha) & 146.8 & 672.8 & 8670.7 & 9367.2 & 5.2 & 18,863 \\
\hline$\%$ & 1 & 4 & 46 & 50 & 0 & \\
\hline
\end{tabular}

The model used to estimating NPP in this research is function of vegetation indices and micrometeorological condition. NDVI of the area derived from remotely sensed data relatively 
small. Although the maximum NDVI for forest at Kalampangan site is between $0.4-0.5$, but the highest percentage of NDVI value is only between $0.3-0.4$. In year 2001. The highest percentage of NDVI is between $0.2-0.3$ ( $81 \%$ of site), following by NDVI range $0.3-0.4$ with area reach $14 \%$. NDVI values estimated for year 2002 have same pattern with 2001 where the highest percentage of NDVI is between $0.2-0.3$ ( $55 \%$ of site), following by NDVI range $0.3-0.4$ with area reach $41 \%$. In year 2003, the highest percentage of NDVI is between $0.3-0.4$ ( $59 \%$ of site), following by NDVI range $0.4-0.5$ with area reach $31 \%$. The increasing of NDVI in year 2003 did not follow by NDVI condition in 2004 where the NDVI then decreased. In 2004 the highest percentage of NDVI is between $0.2-0.3$ ( $55 \%$ of site), following by NDVI range $0.3-0.4$ with area reach $39 \%$.

Goetz et al (1999) shown that only $35 \%$ of the variability of NPP was explained by the annual sum of NDVI, thus in case of mapping of NPP value, the NPP map was not a simple transformation of vegetation indices map derived from satellite. Furthermore, Goetz et al (1999) declared that there are two variables that had the strongest effect of the values of NPP estimated, which are vapor pressure deficit ( $v p d)$ and absorbed PAR. In this research, absorbed PAR is representing in fAPAR that derived from equation using NDVI as input. It does explain why the distribution of NDVI forest around the Kalampangan site will affecting the NPP valued estimated. Figure 7 shown map display of NPP estimated at Kalampangan site year 2001 -2004.

\section{NPP from micrometeorogical measurement}

The difference parameter used to estimate NPP values using remotely sensed data and micrometeorological measurement is a parameter of vegetation condition. All parameter used to estimate an NPP value is from micrometeorological measurement. NDVI values were derived from solar radiation and PAR measured in tower. Furthermore, daily NDVI is used to estimate daily fPAR based on equation introduced by Ruimy et al (1994). The NPP value is derived from single position that is tower. With assume that the peat swamp forest is relatively homogeny, the result can be used to representing all area in peat swamp forest in Kalampangan site. Figure 8 shown Simulated NPP $\left(\mathrm{gC} \mathrm{m}^{-2} \mathrm{yr}^{-1}\right)$ at Kalampangan site derived from micrometeorological measurement using data year $2001-2004$.

The pattern of NPP estimated is increase since year 2002 to 2003 and then decrease from 2003 to 2004 . The range of yearly NPP for study site is between $2000-3000 \mathrm{gC} \mathrm{m}-2$ year $^{-1}$. The range of NPP estimated is similar with result of June (2004) that estimated NPP value for Lore Lindu National Park, Central Sulawesi, Indonesia. The highest NPP for Kalampangan site using this approach is in year $2003\left(2572 \mathrm{gC} \mathrm{m}^{-2}\right.$ year $\left.^{-1}\right)$, followed by year 2001 where the NPP estimated is $2540 \mathrm{gC} \mathrm{m}^{-2}$ year $^{-1}$ and year 2004 with NPP $2047 \mathrm{gC} \mathrm{m}^{-2}$ year $^{-1}$. This pattern is almost similar with the yearly NPP pattern derived from remotely sensed data. 
Yon Sugiarto, Tania June dan Bambang Sapto P.
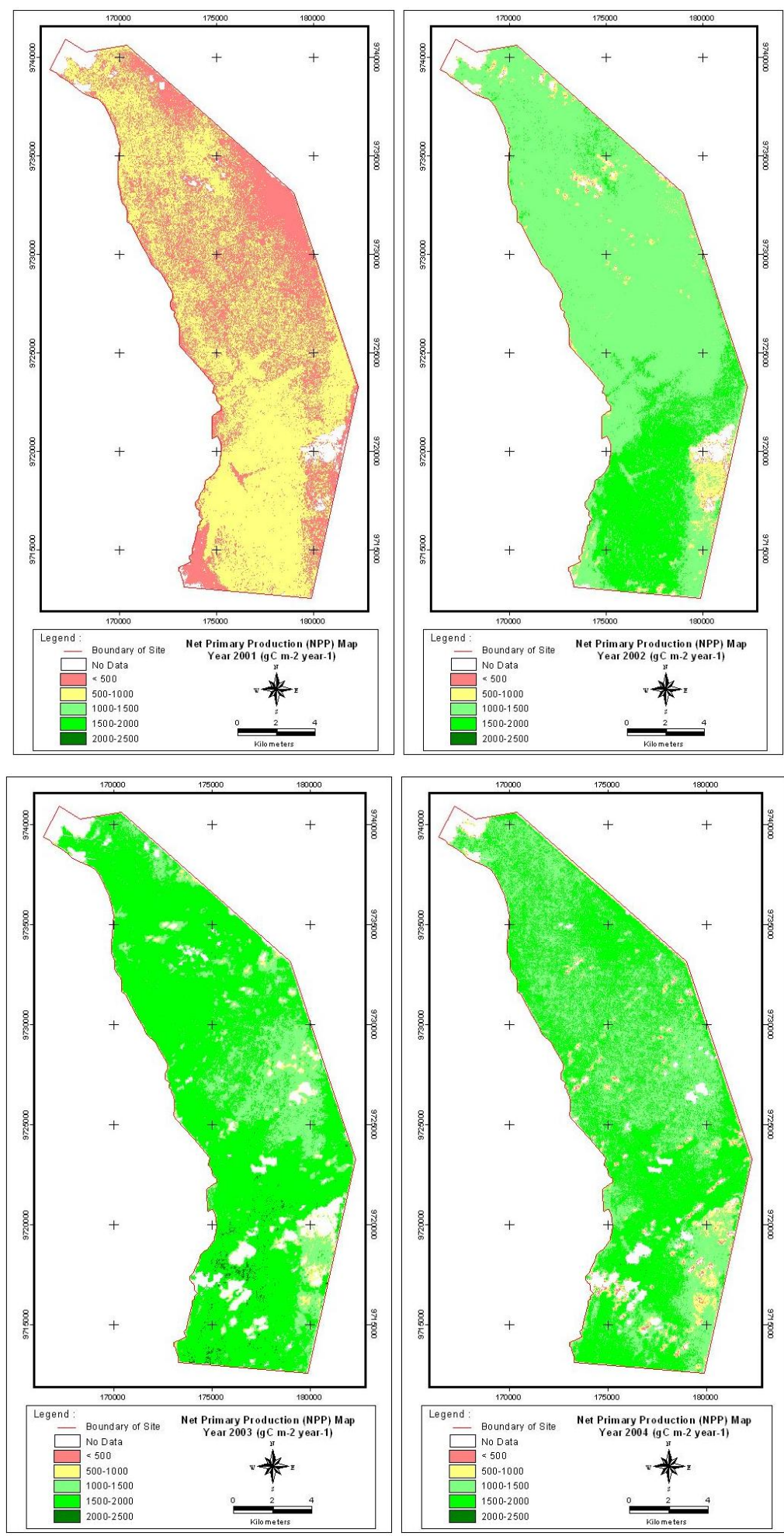

Figure 7. Map display of NPP at Kalampangan site derived from remote sensing data 2001-2004 


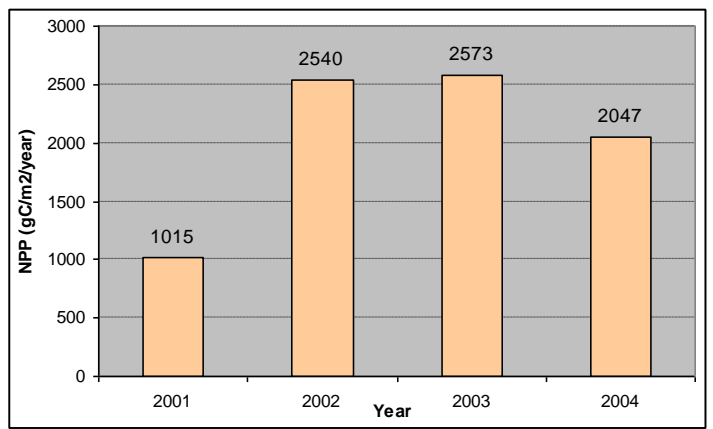

Figure 8. Simulated NPP $\left(\mathrm{gC} \mathrm{m}^{-2} \mathrm{yr}^{-1}\right)$ at Kalampangan site derived from micrometeorological measurement using data year $2001-2004$

Figure 9 shown the monthly NPP simulated at Kalampangan site derived from micrometeorological measurement using data year $2001-2004$. Both table and figure are shown the highest monthly NPP in December for 2002 and 2004. Meanwhile, for 2003 the highest monthly NPP is in August, meanwhile the lowest monthly NPP is in November and December. The result for 2003 is quite impressive because on August is peak of dry season. Goetz et al (1999) shown that vapor pressure deficit (vpd) and APAR are two parameters that have strongest effect on the value of NPP estimated. Vpd is an important environmental control of photosynthesis, which defined as the different between saturated and actual vapor pressure. In environment, the higher vpd value indicated the atmospheric condition is more dry rather that the condition with less vpd. In rainy season, vpd relatively higher rather than dry season because of the higher atmospheric humidity. This result is need more analyzed using longer time series data to study the monthly variability of NPP value estimated.

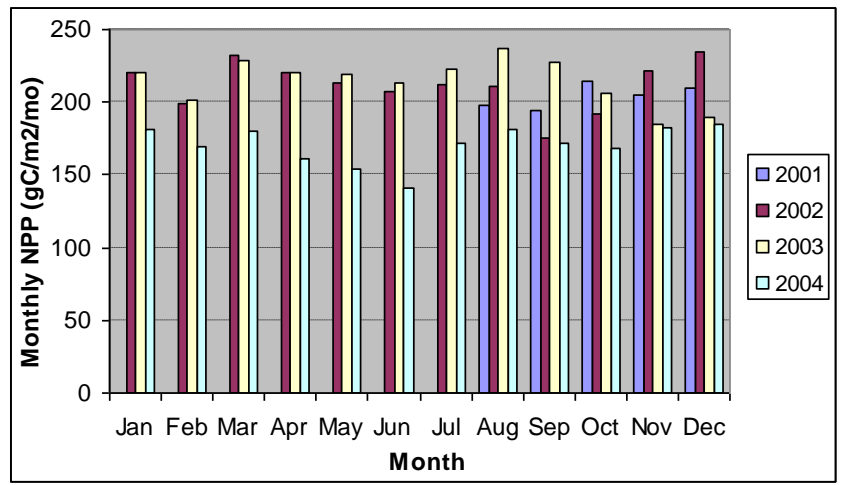

Figure 9. Monthly NPP simulated at Kalampangan site derived from micrometeorological measurement using data year $2001-2004$

In the periode from January to June, the monthly NPP relatively constant for 2002 and 2003. Started in July until December, the NPP value for 2002 is decrease comparing to NPP for 2003. Meanwhile, started in the mid July 2002 moderate El Niño episode has begun and continue until early 2003 (IRI, 2002). This ENSO phenomenon created a drier condition in the atmosphere that affected larger area in Indonesia, include central Kalimantan. This phenomena also increasing vapor pressure deficit, because it made the atmospheric humidity lower than the average condition. 
Yon Sugiarto, Tania June dan Bambang Sapto P.

Based on the data recorded since 2001 - 2004, the highest average temperature is in 2002 and the lowest yearly total precipitation in also in year 2002. This data indicated that atmospheric condition in 2002 is affecting the photosynthetic process and influence the potential of yearly NPP value estimated.

\section{CONCLUSIONS AND RECOMENDATIONS}

\section{Conclusion}

Microclimate variation during 2001 - 2002 is relatively constant. In spite of dry season, however some climatic variables such as solar radiation and PPFD started to decrease. Due to the shading caused by the smoke emitted from large scale peatland fires around the forest. In mid 2002 the El Nino phenomenon is started, causing higher air temperature and less precipitation in study area. Air temperature and relative humidity is relatively constant during $2001-2004$, but trend of data shown that year 2004 is colder and drier rather previous years.

Trend NDVI derived using micrometeorological measurement is increase from 2001 to 2002 and then decrease from 2002 to 2004 . This pattern of trend NDVI is also similar with the NDVI derived using remotely sensed data. Average different values (delta) between both methods used to derive NDVI are constant in 0.33 . The relationships analyzes between both methods shown that high relation with $\mathrm{r} 20.98$, although this analyzes used very limited number of data.

Using remotely sensed data, the highest NPP values estimated is in year 2003 . The maximum NPP is between $2000-2500$ (gC m-2 yr-1) but it's only for small area less than $2 \%$ from whole area that around 1900 ha. In 2003, 75\% area has NPP between $1500-2000\left(\mathrm{gC} \mathrm{m}^{-2} \mathrm{yr}^{-1}\right)$, meanwhile for 2002 and 2004 area that has NPP between $1500-2000\left(\mathrm{gC} \mathrm{m}^{-2} \mathrm{yr}^{-1}\right)$ only $21 \%$ and $50 \%$ respectively. NPP values estimated using micrometeorological measurement have different values but same pattern with NPP estimated using remotely sensed data. The pattern of NPP is increase from year 2002 to 2003 and then decrease from 2003 to 2004. The range of yearly NPP for study site is between $2000-3000 \mathrm{gC} \mathrm{m}^{-2}$ year $^{-1}$. The range of NPP estimated is similar with result of June (2004) that estimated NPP value for Lore Lindu National Park Central Sulawesi, Indonesia. The highest NPP for Kalampangan site using this approach is in year 2003 (2572 gC m

${ }^{2}$ year $^{-1}$ ), followed by year 2001 where the NPP estimated is $2540 \mathrm{gC} \mathrm{m}^{-2}$ year $^{-1}$ and year 2004 with NPP $2047 \mathrm{gC} \mathrm{m}^{-2}$ year $^{-1}$.

There is strong correlation between of NPP values derive using both methods with $\mathrm{r} 2=$ 0.98. Although the result show high correlation. but still need further research. Continuous micrometeorological measurement from tower that still running. can be used to support the data for further research. It has been shown that remote sensing approach and plant physiological modeling using micrometeorological measurement is able to use to estimate net primary production (NPP). NPP values estimated using both approach is different. but still in same or similar pattern. The main factor that caused different result of NPP estimates is different approach that used to 
derived vegetation indices parameter. This parameter than will used to estimate fraction absorbed photosinthetically active radiation (fAPAR).

\section{Recommendations}

The research is still pre-elementary research that should be supported by more precise of further research. The limitation of this research is lack of remotely sensed data used. The recommendation for further research is to use more remotely sensed data with better temporal resolution and moderate spatial resolution such as ASTER or MODIS data. Most of NDVI relationship with plant parameter used in this research has not based on site specific measurement. It is important to develop site specific relationship between NDVI with fAPAR and NDVI with LAI and also involving site specific photosynthetic parameter to increase the result accuracy of the NPP simulated.

\section{REFERENCES}

Clark. D.A.. S. Brown. D. W. Kicklighter. J. Q. Chambers. J. R. Thomlinson. and J. Ni. 2001. Measuring Net Primary Production In Forests: Concepts And Field Methods. Ecological Applications. 11(2). 2001. pp. 356-370

Cohen. W. B. 1991. Response of Vegetation Indices to Changes in Three Measures of Leaf Water Stress. Photogrammetric Engineering \& Remote Sensing. 57(2):195-202

Dixon. R. K.. S. Brown. R. A. Houghton. A. M. Solomon. M. C. Trexler. and J. Wisniewski. 1994. Carbon pools and flux of global forest ecosystem. Science 263:185-190.

Deering. D. W.. Rouse. J. W.. Haas. R. H. \& Schell. J. A. 1975. Measuring Forage Production of Grazing Unit From Landsat MSS Data. Proceeding. Tenth International Symposium on Remote Sensing of Environment. Ann Harbor ERIM. 2:1169-1178.

Fang. J.. Piao. S.. Tang. Z.. Peng. C.. Ji. W. 2001. Annual variability in NPP and precipitation. Sciencemag. 293:1723

Frederick. M.. Gandharum L.. Gunawan. I.. Handoko. Karsidi. A.. Muchlis. M.. Rahmadi A.. and Sanjaya. H. 2001. Inter-annual Dynamics of Deforestation in Southeast Asia : Is The Missing Sink for Carbon In Land Cover Change. Final Report. LCLUC Team. Jakarta.

Goetz. S. J. and S. D. Prince. 1996. Remote sensing of net primary production in boreal forest stands. Agricultural and Forest Meteorology. 78(3): 149-179.

Goetz. S. J. and S. D. Prince. 1998. Variability in carbon exchange and light utilization among boreal forest stands: implications for remote sensing of net primary production. Canadian Journal of Forest Research. 28(3): 375-389.

Goetz. S. J. and S. D. Prince. 1998. Modeling terrestrial carbon exchange and storage: evidence and implications of functional convergence in light use efficiency. Advances in Ecological Research. 28 : 57-92.

Hirano. T.. Osaki. M.. Tani. H.. Hirata. R.. Mogami. J.. Gamo. M.. June. T.. Segah. H.. Kulu. I. P. \& Limin. S. H. 2003. Microclimate of a tropical peat swamp forest in Central Kalimantan. Indonesia from 2001 - 2003. Environmental conservation and land uses management of wetland ecosystem in Southeast Asia. Annual report 2002-2003: 80 -87

Huemmrich. K. F.. Black. T. A.. Jarvis. P.G.. McCaughey. J. H. \& Hall. F. F. 1999. High Ttemporal NDVI pehenology from midrometeorological radiation sensors. J. Geophys. Res. 104:2793527944 
Yon Sugiarto, Tania June dan Bambang Sapto $P$.

Humphries. S. W.. Long S. P. 1995. Windows Intuitive Model of Vegetation Response to Atmosphere and Climate Change. Computer Application in the Biosciences. 11:361-371

Ibrahim. 2001. Environment and Development in Coastal Region and in Small Island. Assessing Mangrove Leaf Area Index and Canopy Closure.

IRI. 2002. ENSO QUICK LOOK December. 2002: A monthly summary of the status of EI Nino. La Nina and the Southern Oscillation (ENSO).

June. T. 2002. Environmental Effects on photosynthesis of C3 plants: scaling up from electron transport to the canopy (Study case: Glycine max L. Merr). Environmental Biology. Research School of Biological Sciences. Australian National University. Canberra.

June. T. 2004. Development of Mechanistic Model for CO2 Absorption of Forest and Plantation. Study Case Lore Lindu National Park. Biotrop-ICSEA. 22p.

Malhi. Y.. Baldocchi. D.D. and Jarvis. P.G. 1999. The carbon balance of tropical. temperate and boreal forests. Plant. Cell and Environment. 22:715-740

Melillo J. M.. Xiao X.. Kicklighter D. W.. Pan Y.. McGuir A. D. and Helfrich J. 1993. Net Primary Production of Terrestrial Ecosystems in China and Its Equilibrium Responses to Changes in Climate and Atmospheric CO2 Concentration. Paper Submitted to Journal of Acta Phytoecologia Sinica.

Melillo. J. M.. I. C. Prentice. G. D. Farquhar. E.-D. Schulze and O. E. Sala. 1996. Terrestrial biotic responses to environmental change and feedbacks to climate. Pages $445-481$ in J. T. Houghton. L. G. Meira Filho. B. A. Callander. N. Harris. A. Kattenberg. and K. Maskell. editors. Climate change 1995: the science of climate change. Cambridge University Press. London. UK

Mickler R. A.. Earnhardt T. S.. Moore J. A. 2002. Modeling and Spatially Distributing Forest Net Primary Production at the Regional Scale. Journal of the Air and Waste Management Association. 52:174-185.

Monteith. J.L. 1972. Solar radiation and productivity in tropical ecosystems. Journal of Applied Ecology. 9: 747-766.

Monteith. J.L. 1977. Climate and the Efficincy of Crop Production in Britain. Philosphical Transactions of the Royal Society of London. 281: 277-294.

Monteith. J.L.; Unsworth. M.H. 1990. Principles of Environmental Physics. Edward Arnold. London. UK

Ochi. S. \& Shibasaki. R. 1999. Estimation of NPP based Agricultural Production for Asian Countries using Remote Sensing Data and GIS. Institute of Industrial Science. University of Tokyo. Japan.

Page. S. E.. Siegert. F.. Rieley. J. O.. Boehm. H. V.. Jaya. A. \& Limin. S. 2002. The amount of carbon released from peat and forest fires in Indonesia during 1997. Nature. 420: 61-65.

Ruimy. A.. Saugier. B. \& Dedier. G. 1994. Methodology for Estimation of Terrestrial NPP from Remotely Sensed Data. Journal of Geophysical Research. 99(3):5263-5283.

Waring R. H.. Landsberg J. J.. Williams M. 1998. Net Primary Production of Forest: a Constants Fraction of Gross Primary Production?. Journal of Tree Physiology. 18:129 - 134. 